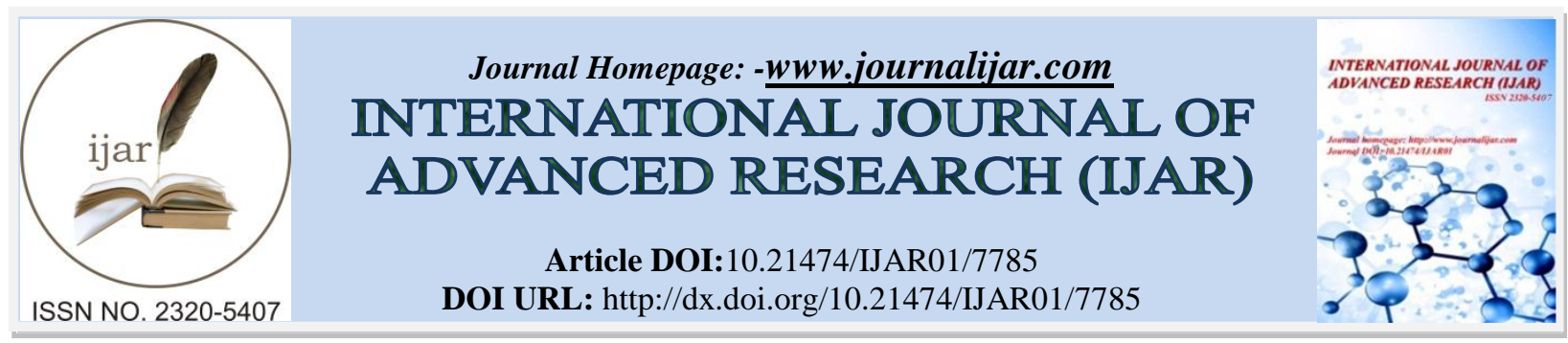

RESEARCH ARTICLE

\title{
INHIBITORY EFFECT OF WILD ONION (ASPHODELUS TENUIFOLIUS CAV.) ON THE SEEDLING GROWTH OF ZEA MAYS L.
}

\author{
S. S.Gautam and G.P.Satsangi. \\ Department of Botany, Dayalbagh Educational Institute, Dayalbagh, Agra-282005 (India).
}

\section{Manuscript Info}

Manuscript History

Received: 2 August 2018

Final Accepted: 4 September 2018

Published: October 2018

\begin{abstract}
Allelopathy is a mechanism in which allelo-chemicals produced by plants may inhibit or enhance the associated plant growth. In the present investigation it is observed that the higher concentration of shoot and seed extracts of Asphodelus tenuifolius Cav. have shown the inhibitory effect on germination of the tested crop, Zea mays L. Further, different concentrations of shoot and seed extracts of $A$. tenuifolius Cav. have shown significant inhibitory effect on germination of seedlings and growth attributes of Zea mays L. Plants, which were not treated with any extracts (control) showed maximum germination and growth pattern. Whereas at lower concentrations of shoot and seed extracts of A. tenuifolius Cav., significant growth was observed in shoot and root length of Zea mays L.
\end{abstract}

Copy Right, IJAR, 2018,. All rights reserved.

\section{Introduction:-}

Allelopathy is a mechanism, in which specific chemical substances released by live or dead/decaying plants cause interference with associated plant community (Harper, 1977) including bacteria and fungi. These chemical substances are called as allelochemicals which may impart inhibitory or rarely stimulatory effects on the germination and growth parameters of associated plants. Allelopathy is a wide research area which has been conducted in various fields of agricultural and allied sciences. It is an emerging science and potential area of research for future sustainable agriculture. It is eco-friendly, can save the available resources and also may mitigate the serious problems raised by synthetic agrochemicals. The allelochemicals produced by plants are basically the byproducts of primary metabolic processes. Current research in this area is focused on the effects of weeds on crops and crops on weeds (Jabeen et al., 2011).

Weeds are invasive plants which are not only consume the soil nutrients, available moisture but also compete for space and sunlight with economically important plants, thereby causing yield reduction of valuable crops. In addition, weeds decrease the quality and quantity of agricultural products and consequently reduce their market value (Hanif et al., 2004; Pervaiz \& Quazi, 1999). Asphodelus tenuifolius Cavase also called as wild onion is a native to the Mediterranean region and Macaronesia, but now it is widespread through the Arabian Peninsula to the Indian Subcontinent. It is also spreading in Malaysia, Australia, Chile, New Zealand, Mexico and United States of America (Nasir \& Ali, 1989). Wild weed (Asphodelus tenuifolius Cav.) is declared as noxious weed in several countries and can be easily seen in sand soils of Indo-Pak sub-continent. Its control is a desired and the major component of management in the production system (Norris, 1982; Young et al., 1996). In present investigation 
attempts were made to explore the allelopathic effect of Asphodelus tenuifolius Cav. on the germination and growth attributes of Zea mays L.

\section{Materials and methods:-}

\section{Collection of test weed}

Healthy plants of A. tenuifolius were selected to prepare tested solutions and collected from agricultural farms of Dayalbagh, Agra. Plant samples were washed and then allowed them to dry at room temperature $\left(27^{\circ} \mathrm{C}\right)$ in shade.

\section{Extract preparation of test weed}

To prepare extract of tested weed plants, the plants materials i.e., shoot and seeds were crushed and allowed to decay in distilled water for $24 \mathrm{hrs}$ in the ratio of 1:10 (plant material: water). Extraction of leachates was done by using the sieve ( $2 \mathrm{~mm}$ mesh) to make its different concentration $(25 \%, 50 \%, 75 \%, \& 100 \%)$.

\section{Sterilization}

Glass wares were sterilized before their use in experiment at $121^{\circ} \mathrm{C}, 15 \mathrm{lb} / \mathrm{cm}^{3}$ pressure for $15 \mathrm{~min}$. and seeds of the selected crop were surface sterilized by $\mathrm{HgCl}_{2}$ (mercuric chloride) before conducting experimentation.

\section{Bioassay}

Bioassay was done to identify effective concentrations of tested weed extract for its allelopathic activity on germination and growth parameters of Zea mays L. In vivo study was conducted under field conditions with the prepared extracts. 10 seeds of maize (Zea mays) were soaked in each concentrations of extract for 24 hours. The soaked seeds were transferred in pots filled with soil. $25 \mathrm{ml}$ of extract has been poured in soil at the day of seed transfer. $5 \mathrm{ml}$ of extract was sprayed on germinated plants at alternate days. The germination of seed, root length, shoot length and dry weight of plants was recorded at $15^{\text {th }}$ day after sowing in vivo.

\section{Experimental design and statistical Analysis}

Experiments in triplicates by following randomized block design were conducted. Growth parameters i.e., germination, root length, shoot length were recorded at 15 days after sowing (DAS). Collected data was tabulated and analyzed statistically.

\section{Results and Discussion:-}

\section{Germination effect:}

The table-1, shows that in shoot extract of A. tenuifolius Cav. the shoot length and germination percentage of maize were decreased significantly. Further, among the applied extract concentrations the maximum germination found in control and minimum germination was found in pure extract i.e. $100 \%$, which showed significant negative effect. The shoot extract exhibited the inhibition of shoot length $2.96 \%, 9.67 \%, 10.63 \%$ and $11.03 \%$ as percentage change over from its control in the different concentrations. The similar pattern was obtained in case of root length where in the root length of maize inhibited $4.31 \%, 9.31 \%, 16.62 \%$ and $22.55 \%$ in the different extract concentrations of Asphodelous tenuifolious Cav. over control respectively.

By perusal of the table-2 growth in shoot length and root length found decreased as the increase in concentration of seed extract of Asphodelous tenuifolious cav. respectively. Shoot length showed 9.63, 22.43, 29.21 and 34.82\% change over control and similar trend in root length also observed. It clearly shows that there is inverse relationship between root, shoot length and concentration of seed extract of A. tenuifolious Cav. where in the root length of maize inhibited $9.15 \%, 29 \%, 33.43 \%$ and $54.30 \%$ in the different extract concentrations of Asphodelous tenuifolious Cav. over the control respectively.

\section{Fresh weight /dry weight:}

The table -1 further reveals that shoot extract of A. tenuifolious Cav. inhibited fresh weight of Zea mays L. by $11.98 \%, 17.39 \%, 23.10 \%$ and $29.10 \%$ over control . The inhibitory effect increased with dose or vice versa. The inhibitory effect of shoot extract on the dry weight was $17.5 \%, 32 \%, 37.5 \%$ and $44 \%$ over control in the extracts respectively. Fresh Weight / Dry Weight ratio was found significant increase with the different concentrations of shoot extract. 
Seed extract of Asphodelous tenuifolious Cav. Inhibited fresh weight of Zea mays L. by 23.15\%, 33.05\%, 53.47\% and $61.05 \%$ over control. The inhibitory effect increased with dose or vice versa. The inhibitory effect of shoot extract on the dry weight was $7.36 \%, 16.84 \%, 38.94 \%$ and $48.12 \%$ over control in the extracts respectively. Fresh Weight / Dry Weight ratio significantly decreases with the concentration of extract. (Table-2)

Present finding is in the conformity of the earlier findings of Mishra et. al. (2001),Babar et. al., (2009), Nasiraet.al.,(2009) and Gautam and Satsangi obtained in their studies.

\section{Conclusion:-}

Thus, it can be concluded that both the shoot and seed extracts of A. tenuifolious Cav. bears direct inhibitory allelopathic effect over germination and seedling growth of Zea mays L. So more emphasis should be given to eradicate the $A$. tenuifolious Cav. weed from the maize crop fields.

\section{Acknowledgement:-}

Authors are grateful to Prof. P.K.Kalra Director of the Institute, Prof. J.N.Srivastava Head, Department Of Botany for their encouragement and support.

Table 1:-Germination, Shoot Length and Root Length of Zea mays L. seeds sprayed in shoot extract of Asphodelous tenuifolious Cav. as on 15 DAS.

\begin{tabular}{|c|c|c|c|c|c|c|c|c|c|c|}
\hline $\begin{array}{l}\text { Concentrati } \\
\text { on }\end{array}$ & $\begin{array}{l}\text { Germinati } \\
\text { on } \\
(\%)\end{array}$ & $\begin{array}{l}\text { Shoot } \\
\text { Length } \\
(\mathrm{cm})\end{array}$ & $\begin{array}{l}\text { \% } \\
\text { Chan } \\
\text { ge } \\
\text { Over } \\
\text { Contr } \\
\text { ol }\end{array}$ & $\begin{array}{l}\text { Root } \\
\text { Length } \\
(\mathrm{cm})\end{array}$ & $\begin{array}{l}\% \\
\text { Chan } \\
\text { ge } \\
\text { Over } \\
\text { Contr } \\
\text { ol }\end{array}$ & $\begin{array}{l}\text { Fresh } \\
\text { Weight } \\
\text { (gms) }\end{array}$ & $\begin{array}{l}\% \\
\text { Chan } \\
\text { ge } \\
\text { Over } \\
\text { Contr } \\
\text { ol }\end{array}$ & $\begin{array}{l}\text { Dry } \\
\text { Weight } \\
\text { (gms) }\end{array}$ & $\begin{array}{l}\% \\
\text { Chan } \\
\text { ge } \\
\text { Over } \\
\text { Contr } \\
\text { ol }\end{array}$ & $\begin{array}{l}\text { FW/D } \\
W\end{array}$ \\
\hline 0 & $95 \%$ & $\begin{array}{l}19.94 \pm 3 . \\
01\end{array}$ & - & $\begin{array}{l}18.89 \pm 0 . \\
07\end{array}$ & - & $\begin{array}{l}6.84 \pm 1 . \\
55\end{array}$ & - & $\begin{array}{l}2.02 \pm 1 . \\
13\end{array}$ & - & 3.38 \\
\hline 25 & $90 \%$ & $\begin{array}{l}19.35 \pm 1 \\
14\end{array}$ & -2.96 & $\begin{array}{l}18.03 \pm 0 . \\
92\end{array}$ & -4.31 & $\begin{array}{l}6.02 \pm 2 . \\
12\end{array}$ & $\begin{array}{l}- \\
11.98\end{array}$ & $\begin{array}{l}1.65 \pm 0 . \\
21\end{array}$ & -17.5 & 3.64 \\
\hline 50 & $85 \%$ & $\begin{array}{l}18.01 \pm 0 . \\
14\end{array}$ & -9.67 & $\begin{array}{l}17.13 \pm 1 \\
86\end{array}$ & -9.31 & $\begin{array}{l}5.65 \pm 0 . \\
77\end{array}$ & $\begin{array}{l}- \\
17.39\end{array}$ & $\begin{array}{l}1.36 \pm 0 . \\
08\end{array}$ & -32 & 4.15 \\
\hline 75 & $85 \%$ & $\begin{array}{l}17.82 \pm 1 \\
57\end{array}$ & $\begin{array}{l}- \\
10.63\end{array}$ & $\begin{array}{l}15.75 \pm 0 . \\
17\end{array}$ & $\begin{array}{l}- \\
16.62\end{array}$ & $\begin{array}{l}5.26 \pm 0 . \\
98\end{array}$ & $\begin{array}{l}- \\
23.10\end{array}$ & $\begin{array}{l}1.25 \pm 0 . \\
07\end{array}$ & -37.5 & 4.20 \\
\hline 100 & $75 \%$ & $\begin{array}{l}17.74 \pm 3 . \\
64\end{array}$ & $\begin{array}{l}- \\
11.03\end{array}$ & $\begin{array}{l}14.63 \pm 1 \\
07\end{array}$ & $\begin{array}{l}- \\
22.55\end{array}$ & $\begin{array}{l}4.85 \pm 0 . \\
28\end{array}$ & $\begin{array}{l}- \\
29.10\end{array}$ & $\begin{array}{l}1.12 \pm 0 . \\
09\end{array}$ & -44 & 4.33 \\
\hline
\end{tabular}

Table 2:-Germination, Shoot Length and Root Length of Zea mays L. in seed extract of Asphodelous tenuifolious Cav. on 15 DAS.

\begin{tabular}{|c|c|c|c|c|c|c|c|c|c|c|}
\hline $\begin{array}{l}\text { Concen } \\
\text { tration }\end{array}$ & $\begin{array}{l}\text { Germi } \\
\text { nation } \\
(\%)\end{array}$ & $\begin{array}{l}\text { Shoot } \\
\text { Length } \\
(\mathrm{cm})\end{array}$ & $\begin{array}{l}\% \\
\text { Change } \\
\text { Over } \\
\text { Control }\end{array}$ & $\begin{array}{l}\text { Root } \\
\text { Length } \\
(\mathrm{cm})\end{array}$ & $\begin{array}{l}\% \\
\text { Change } \\
\text { Over } \\
\text { Control }\end{array}$ & $\begin{array}{l}\text { Fresh } \\
\text { Weight } \\
\text { (gms) }\end{array}$ & $\begin{array}{l}\% \\
\text { Change } \\
\text { Over } \\
\text { Control }\end{array}$ & $\begin{array}{l}\text { Dry } \\
\text { Weight } \\
\text { (gms) }\end{array}$ & $\begin{array}{l}\% \\
\text { Change } \\
\text { Over } \\
\text { Control }\end{array}$ & $\begin{array}{l}\text { FW/ } \\
\text { DW }\end{array}$ \\
\hline 0 & $85 \%$ & $\begin{array}{l}22.11 \pm \\
1.74 \\
\end{array}$ & - & $\begin{array}{l}21.95 \pm \\
1.41 \\
\end{array}$ & - & $4.75 \pm 0.28$ & - & $\begin{array}{l}0.95 \pm 0.0 \\
7\end{array}$ & - & 5.00 \\
\hline 25 & $60 \%$ & $\begin{array}{l}19.98 \pm \\
2.75\end{array}$ & -9.63 & $\begin{array}{l}19.94 \pm \\
3.01\end{array}$ & -9.15 & $3.65 \pm 0.35$ & -23.15 & $\begin{array}{l}0.88 \pm 0.2 \\
1\end{array}$ & -7.36 & 4.14 \\
\hline 50 & $45 \%$ & $\begin{array}{l}17.15 \pm \\
2.57\end{array}$ & -22.43 & $\begin{array}{l}15.58 \pm \\
2.20\end{array}$ & -29.00 & $3.18 \pm 0.48$ & -33.05 & $\begin{array}{l}0.79 \pm 0.4 \\
9\end{array}$ & -16.84 & 4.02 \\
\hline 75 & $30 \%$ & $\begin{array}{l}15.65 \pm \\
0.17 \\
\end{array}$ & -29.21 & $\begin{array}{l}14.61 \pm \\
0.70\end{array}$ & -33.43 & $2.21 \pm 0.21$ & -53.47 & $\begin{array}{l}0.58 \pm 0.3 \\
5\end{array}$ & -38.94 & 3.82 \\
\hline 100 & $25 \%$ & $\begin{array}{l}14.41 \pm \\
1.71\end{array}$ & -34.82 & $\begin{array}{l}10.03 \pm \\
0.70\end{array}$ & -54.30 & $1.45 \pm 0.07$ & -61.05 & $\begin{array}{l}0.49 \pm 0.0 \\
7\end{array}$ & -48.12 & 3.77 \\
\hline
\end{tabular}




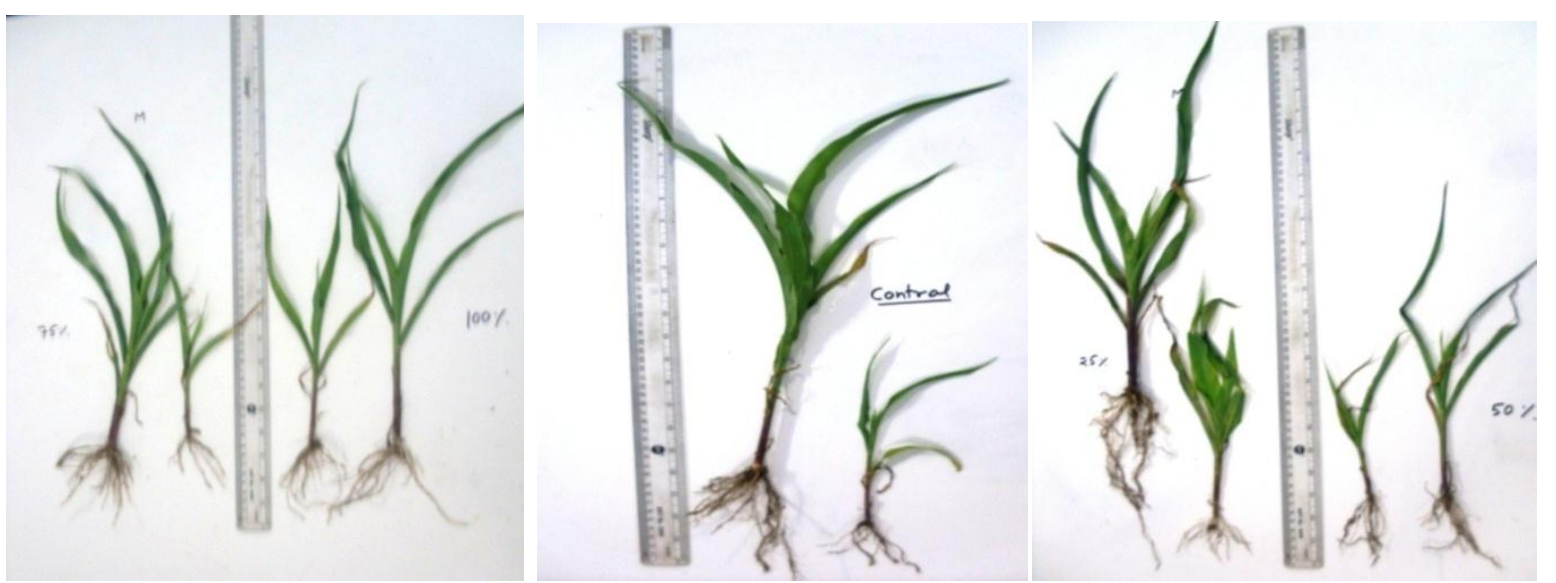

Plate 1:-Shoot Length and Root Length of Zea mays L. in shoot extract of Asphodelous tenuifolious Cav. on 15 DAS

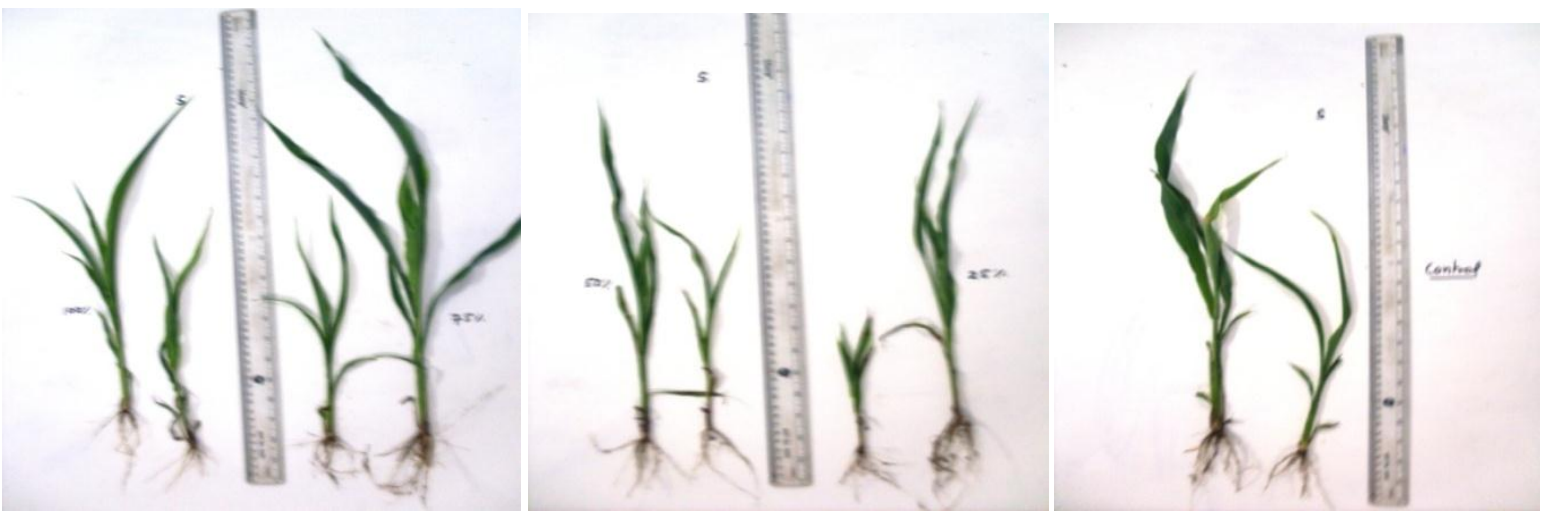

Plate 2:- Shoot Length and Root Length of Zea mays L. in seed extract of Asphodelous tenuifolious Cav. on 15 DAS

\section{References:-}

1. Babar, B.H., Tanveer A., Tahir M., Aziz A., Ahmad A.H., Nadeem M.A. and Javaid M.M., (2009) Allelopathic potential of wild onion (Asphodelustenuifolius) on the germination and seedling growth of chickpea (Cicer arietinum). Weed Biol. Manage., 9: 146-151

2. Hanif, Z., Khan S.A., Marwat B. K.., Khan A.I. and Ikramullah. (2004) Important weeds of wheat crop of Malakandher Farm, 1.Agricultural University, Peshawar. Pak. J. Weed. Sci. Res., 10: 109-112.

3. Harper, J.L. (1977).Population biology of plants. Academic Press, New York.

4. Mishra J.S., Swain D. and Singh V.P. (2001) Allelopathic effect of Asphodelus tenuifolius on wheat, mustard, lentil and chickpea. Pestology 25: 48-50.

5. Nasir, E. and Ali S.I.(1980-1989). Flora of Pakistan.Eds. No.132-190. P. A. R.C. Islamabad.

6. Nasira J., M. Ahmed (2009) Possible Allelopathic Effects of three Different weeds on Germination and Growth of Maize. Pak. J.Bot.,41(4):1677-1683.

7. Nasira J., Ahmed M., Shaukat S.S. (2011) Interactive Activity of Asphodelus tenuifolius on germination and growth of Wheat (Triticum aestivium 1.) and Sorghum (Sorghum bicolor 1.) Pak. J. Bot., 43(1): 325-331.

8. Norris, R.F. (1982) Interaction between weeds and other pests in the agroecosystem 406. In: Proc. Conf. on Biometeorology in Integrated Pest Management, (Eds.): J.L. Hatfield and I.J. Thomson. Uni. of California, Davis, Academic press. New York.

9. Pervaiz, K. and Quazi M.H. (1999) Status of food production in Pakistan. Progr. Farming.,

10. 12: 15 .

11. Rai, D.K., Chatterjee R., Sharangi A.B., Pariari A. and Chattopadhyay P.K., (2003) Performance of garlic (Allium sativum L.) cultivars in new alluvial zone of West Bengal TheHort.J.,16:71-75.

12. Young, F.L., Ogg Jr A.G., Young D.L. and Papendick R.I.( 1996) Weed management for crop production in the North West wheat (Triticum aestivum L.) region. Weed Sci., 44: 429-436. 